\title{
Measurement of Operating Efficiency of Property Insurance Companies in China
}

\author{
Xiangyan Meng ${ }^{1, *}$
}

${ }^{1}$ Institute of Insurance, Shandong University of Finance and Economics, Ji'nan, Shandong, China

*Corresponding author. Email: mengxiangyan03@126.com

\begin{abstract}
The operation of property insurance companies is directly related to the healthy and stable development of insurance industry. Based on the operating data of 38 property insurance companies from 2009 to 2014, we observed the change trend of total factor productivity through the Malmquist index. On this basis, we constructed Super-SBM DEA model (Slacks-based measure of super-efficiency in data envelopment analysis developed by Tone) to measure the operating efficiency of 38 property insurance companies. The research shows that the total factor productivity of property insurance companies showed a downward trend on the whole during the sample period. The operating efficiency of property insurance companies in China is at a low level. The operating efficiency of domestic property insurance companies is higher than that of foreign companies. There were significant differences in Super-SBM efficiency values among insurance companies.
\end{abstract}

Keywords: property insurance, operational efficiency, Super-SBM DEA

\section{INTRODUCTION}

In recent years, as an important part of the insurance industry, China's property insurance market has developed rapidly. From 2009 to 2014, the total assets of China's property insurance industry increased from 489 billion yuan to 1.40 trillion yuan, with an average annual growth rate of $23.4 \%$. The premium income of property insurance industry increased from 299 billion yuan to 744 billion yuan, with an average annual growth rate of 20.3 percent. With the rapid growth of property insurance industry, its internal competition subjects are increasing, and the market competition environment is becoming increasingly fierce. In this context, it has become the primary goal to improve the company's operating efficiency and gradually realize the transformation from the pure pursuit of premium scale mode to the efficiency-centered concentric mode of development. Therefore, the measurement of insurance company efficiency has been one of the research hotspots in this field.

\section{LITERATURE REVIEW}

As for the measurement of the operating efficiency of insurance companies, Weiss (1991), Cummins and Weiss (1993) introduced the cutting-edge efficiency analysis method into the insurance field earlier. From the perspective of research methods, measurement methods mainly include stochastic frontier parameter analysis (SFA) and data envelopment analysis (DEA). Due to the strict requirements on function setting and data quality, the application scope of SFA method is limited. Because of its flexibility and applicability, data envelopment analysis (DEA) is widely used in the study of insurance companies' cost efficiency, scale efficiency and technical efficiency. Berger (2000), Diacon (2002), Jeng (2005) et al. used DEA method to analyze the cost efficiency, scale efficiency and technical efficiency of insurance companies in different countries.

With the innovation and improvement of research methods, two-stage or multi-stage DEA method and SBM-DEA method have been used to measure the operating efficiency or financing efficiency of insurance companies. Although the SBM-DEA model takes environmental constraints, undesired output, and input slack into consideration, some decision-making units will still be in a valid state at the same time. In other words, the operating efficiency of different insurance companies will be at the forefront of DEA efficiency at the same time, which is not conducive to the evaluation of decision-making. Accordingly, Tone (2002) combined the characteristics of the superefficiency DEA model and the SBM model to establish a super-efficiency undesired output model (SuperSBM). The Super-SBM method has been applied in many fields in recent years, such as e-commerce website efficiency evaluation, green innovation efficiency evaluation, etc. Therefore, we use the SuperSBM model to measure the operating efficiency of Chinese property insurance companies. 


\section{VARIABLE, METHODOLOGY AND DATA}

\section{A. Methodology and data}

1) Malmquist index: Fare (1989) applied the Malmquist index to the study of production efficiency. As shown in formula (1), when the value of $M$ is greater than 1, total factor productivity shows an increasing trend. On the contrary, total factor productivity shows a downward trend. The Malmqulist index can be decomposed into two parts (formula (2) and (3)): technology change index (TC) and efficiency change index (EC). EC reflects whether the property insurance company operates with the best technology and scale in the insurance industry. TC reflects the change of the best production technology boundary.

$$
M\left(x^{t}, y^{t} ; x^{t+1}, y^{t+1}\right)=\frac{D_{0}^{t+1}\left(x^{t+1}, y^{t+1}\right)}{D_{0}^{t}\left(x^{t}, y^{t}\right)} \times\left[\frac{D_{0}^{t}\left(x^{t+1}, y^{t+1}\right) D_{0}^{t}\left(x^{t}, y^{t}\right)}{D_{0}^{t+1}\left(x^{t+1}, y^{t+1}\right) D_{0}^{t+1}\left(x^{t}, y^{t}\right)}\right]^{1 / 2}
$$

(1)

$$
\begin{aligned}
& E C=D_{0}^{t+1}\left(x^{t+1}, y^{t+1}, b^{t+1}\right) / D_{0}{ }^{t}\left(x^{t}, y^{t}\right) \\
& T C=\left[\frac{D_{0}{ }^{t}\left(x^{t+1}, y^{t+1}\right) D_{0}{ }^{t}\left(x^{t}, y^{t}\right)}{D_{0}^{t+1}\left(x^{t+1}, y^{t+1}\right) D_{0}{ }^{t+1}\left(x^{t}, y^{t}\right)}\right]^{1 / 2}
\end{aligned}
$$

2) Super-SBM: The data envelopment analysis method is an effective tool for measuring the efficiency of similar decision-making units. It has been widely used in the measurement and evaluation of efficiency or productivity among enterprises, industries, regions and countries. Traditional DEA models (such as CCR model, BCC model) did not consider the slackness of input and output. In order to reduce the influence of the deviation caused by the radial direction and the angle, Tone (2003) proposed a non-radial and non-angle model (SBM). The SBM model incorporates slack variables into the objective function.The output efficiency value of the SBM model may make multiple decision-making units in an effective state at the same time, which is not conducive to further evaluation and comparison. Banker et al. proposed a super-efficiency DEA model based on CCR, which further differentiated decision-making units. On this basis, referring to the processing methods of Tone and Hong $\mathrm{Li}$, we adopt the Super-SBM model, the form of which can be written as:

$$
\min \theta^{*}=\frac{\frac{1}{m} \sum_{i=1}^{m} \frac{\bar{x}}{x_{i k}}}{\frac{1}{s_{1}+s_{2}}\left(\sum_{r=1}^{s_{1}} \frac{\bar{y}^{g}}{y_{r k}^{g}}+\sum_{r=1}^{s_{2}} \frac{\bar{y}^{b}}{y_{r k}^{b}}\right)}
$$

$$
\text { s.t. }\left\{\begin{array}{l}
\bar{x} \geq \sum_{j=1, \neq k}^{n} x_{i j} \lambda_{j}, i=1, \ldots, m \\
\bar{y}^{g} \leq \sum_{j=1, \neq k}^{n} y_{r j} \lambda_{j}, r=1, \ldots, s_{1} \\
\bar{y}^{b} \geq \sum_{j=1, \neq k}^{n} y_{r j} \lambda_{j}, r=1, \ldots, s_{2} \\
\lambda_{j} \geq 0 ; \bar{x} \geq x_{k} ; \bar{y}^{g} \leq y^{g} ; \bar{y}^{b} \geq y^{b}
\end{array}\right.
$$

Compared with the traditional DEA model, the Super-SBM model has the following advantages: First, it can effectively solve the slack problem of unit input and output variables. The second is that the obtained efficiency value can exceed 1, allowing comparison between decision-making units.

3) Data: We take 38 property insurance companies in China from 2009 to 2014 as the research objects, including 23 domestic companies and 15 foreign companies. domestic property insurance companies include PICC, AXIC, YDIC, TAIC, TPIC, CLPC, YGIC, TPIC, CCIC, AHIC, CAIC, DBIC, BPIC, ACIC, YAIC, HAIC, YAIC, ECIC, SAIC, CPIC, HTIC, BOCI and DZIC. Foreign companies include HI,MSIG, Sompo-Japan, Samsung Fire, AXA, Zurich, Sun Alliance, Chubb, Cathay, Generali, Tokio Marine, Liberty Mutual, Chartis, Groupama, Allianz. The data involved are derived from the balance sheet, income statement, business statistics and company personnel structure in the "China Insurance Statistical Yearbook".

\section{B. Variable}

Before measuring the efficiency of Super-SBM, the input and output indicators of the model should be determined. Input variables include labor, equity capital, and operating expenses. Drawing on the value-added definition method of Cummins and Weiss (2000), we use premium income and investment income as output variable indicators.

\section{EMPIRICAL RESULTS}

\section{A. Measuring the total factor productivity of property insurance companies}

In this paper, Malmquist index method was used to evaluate and analyze the dynamic efficiency of inputoutput data of 38 property insurance companies in China from 2009 to 2014. The results are shown in "Table I". 
TABLE I. THE AVERAGE VALUE OF THE TFP INDEX FROM 2009 TO 2014

\begin{tabular}{|l|l|l|l|l|l|}
\hline Category & EC & TC & PC & SC & TFP \\
\hline Overall & 0.994 & 0.989 & 0.985 & 1.009 & 0.983 \\
\hline Domestic & 0.967 & 0.999 & 0.963 & 1.004 & 0.968 \\
\hline Foreign & 1.049 & 0.977 & 1.038 & 1.024 & 1.027 \\
\hline Average & 0.994 & 0.989 & 0.985 & 1.009 & 0.983 \\
\hline
\end{tabular}

In "Table I", from 2009 to 2014, the average total factor productivity (TFP) of China's 38 property insurance companies was 0.983 , which was relatively low overall. Total factor productivity shows obvious difference between Chinese property insurance companies and foreign property insurance companies. The total factor productivity of foreign-funded property insurance companies and Chinese-funded property insurance companies was 1.027 and 0.968 respectively. In addition, the technical efficiency and its decomposition index of foreign-funded companies are significantly higher than those of Chinese-funded companies, which indicates that foreign-funded property insurance companies have relatively advanced enterprise management ability and investment technology level. The average TC index of both is less than 1 , indicating that there is still a large room for improvement and improvement in technical level.

\section{B. Measuring the operating efficiency of property insurance companies based on the Super-SBM method}

This section use the Super-SBM method to measure the operating efficiency of 38 property insurance companies. Combined with the input and output indicators, we use MaxDEA software to calculate, as shown in "Table II" and "Table III".

The results show that there are obvious differences in operating efficiency among property insurance companies. It can be seen from "Table IV" that the Super-SBM method made the efficiency value discrimination more obvious (especially when the efficiency score value is greater than 1), which cannot be measured by the classic DEA model and SBM model.

TABLE II. OPERATING EFFICIENCY OF CHINESE PROPERTY INSURANCE COMPANIES

\begin{tabular}{|l|l|l|l|l|l|l|}
\hline Chinese company & 2009 & 2010 & 2011 & 2012 & 2013 & 2014 \\
\hline PICC & 0.675 & 1.358 & 0.743 & 0.892 & 1.364 & 1.814 \\
\hline ECIC & 0.814 & 0.808 & 1.403 & 1.143 & 1.014 & 1.515 \\
\hline SAIC & 1.278 & 0.775 & 0.630 & 0.864 & 1.294 & 1.323 \\
\hline CPIC & 0.951 & 0.932 & 0.849 & 0.823 & 1.235 & 1.244 \\
\hline HTIC & 1.557 & 0.529 & 0.835 & 0.464 & 0.379 & 0.562 \\
\hline TPIC & 0.838 & 0.632 & 0.566 & 0.647 & 0.980 & - \\
\hline CLPC & 0.713 & 0.693 & 0.608 & 0.594 & 0.773 & 0.845 \\
\hline YGIC & 1.017 & 0.434 & 0.578 & 0.618 & 0.640 & 0.802 \\
\hline TPIC & 0.590 & 0.623 & 0.621 & 0.502 & 0.604 & 0.839 \\
\hline CCIC & 0.501 & 0.511 & 0.503 & 0.551 & 0.622 & 0.645 \\
\hline BPIC & 0.998 & 0.468 & 0.350 & 0.353 & 0.490 & 0.533 \\
\hline AXIC & 0.633 & 0.504 & 0.427 & 0.485 & 0.505 & 0.593 \\
\hline YDIC & 0.606 & 0.545 & 0.476 & 0.407 & 0.533 & 0.558 \\
\hline TAIC & 0.591 & 0.538 & 0.474 & 0.442 & 0.514 & 0.551 \\
\hline YAIC & 0.519 & 0.487 & 0.429 & 0.432 & 0.556 & 0.659 \\
\hline HAIC & 0.388 & 0.497 & 0.295 & 0.342 & 0.308 & 0.514 \\
\hline YAIC & 0.414 & 0.285 & 0.277 & 0.213 & 0.421 & 0.697 \\
\hline ACIC & 0.235 & 0.300 & 0.305 & 0.440 & 0.367 & 0.454 \\
\hline BOCI & 0.257 & 0.322 & 0.310 & 0.319 & 0.377 & 0.414 \\
\hline DZIC & 0.376 & 0.317 & 0.242 & 0.309 & 0.410 & - \\
\hline AHIC & 0.239 & 0.239 & 0.171 & 0.343 & 0.326 & 0.630 \\
\hline CAIC & 0.208 & 0.210 & 0.244 & 0.328 & 0.409 & 0.282 \\
\hline DBIC & 0.265 & 0.226 & 0.149 & 0.247 & 0.288 & 0.343 \\
\hline & & & & & & \\
\hline
\end{tabular}


TABLE III. OPERATING EFFICIENCY OF FOREIGN PROPERTY INSURANCE COMPANIES

\begin{tabular}{|l|l|l|l|l|l|l|}
\hline Foreign company & 2009 & 2010 & 2011 & 2012 & 2013 & 2014 \\
\hline HI & 0.950 & 0.910 & 0.891 & 0.950 & 1.187 & 1.171 \\
\hline Cathay & 1.913 & 0.631 & 0.437 & 0.314 & 0.225 & 0.287 \\
\hline Generali & 0.631 & 0.500 & 0.486 & 0.524 & 0.449 & 0.834 \\
\hline Groupama & 0.972 & 0.891 & 0.553 & 0.267 & 0.219 & 0.345 \\
\hline Allianz & 0.640 & 0.559 & 0.521 & 0.452 & 0.481 & 0.532 \\
\hline Samsung Fire & 0.850 & 0.593 & 0.451 & 0.448 & 0.332 & 0.451 \\
\hline AXA & 0.742 & 0.579 & 0.495 & 0.500 & 0.433 & 0.349 \\
\hline Zurich & 0.707 & 0.530 & 0.451 & 0.467 & 0.430 & 0.466 \\
\hline Sun Alliance & 0.554 & 0.443 & 0.480 & 0.537 & 0.486 & 0.550 \\
\hline Chubb & 0.401 & 0.381 & 0.415 & 0.437 & 0.454 & 0.260 \\
\hline MSIG & 0.403 & 0.333 & 0.336 & 0.377 & 0.392 & 0.497 \\
\hline Sompo-Japan & 0.402 & 0.358 & 0.340 & 0.343 & 0.338 & 0.463 \\
\hline Tokio Marine & 0.388 & 0.358 & 0.330 & 0.373 & 0.356 & 0.361 \\
\hline Liberty Mutual & 0.317 & 0.260 & 0.221 & 0.199 & 0.183 & 0.193 \\
\hline Chartis & 0.183 & 0.175 & 0.199 & 0.198 & 0.183 & 0.299 \\
\hline
\end{tabular}

TABLE IV. OPERATING EFFICIENCY(SUPER-SBM/SBM)

\begin{tabular}{|l|l|l|l|l|l|l|}
\hline \multirow{2}{*}{ Year } & \multicolumn{2}{|l}{ Super-SBM } & \multicolumn{2}{l|}{ SBM } \\
\cline { 2 - 7 } & Overall & Domestic & Foreign & Overall & Domestic & Foreign \\
\hline 2009 & 0.650 & 0.633 & 0.670 & 0.497 & 0.475 & 0.532 \\
\hline 2010 & 0.519 & 0.532 & 0.500 & 0.430 & 0.431 & 0.428 \\
\hline 2011 & 0.476 & 0.499 & 0.440 & 0.394 & 0.418 & 0.358 \\
\hline 2012 & 0.477 & 0.511 & 0.426 & 0.386 & 0.415 & 0.342 \\
\hline 2013 & 0.541 & 0.622 & 0.410 & 0.374 & 0.421 & 0.301 \\
\hline 2014 & 0.635 & 0.732 & 0.471 & 0.454 & 0.514 & 0.362 \\
\hline
\end{tabular}

During the study period, the average value of SuperSBM efficiency of 38 sample property insurance companies was relatively low, with a value between 0.4-0.7, and the overall trend was decreasing first and then increasing. Although China's insurance industry has developed rapidly in recent years and the market operating environment has improved significantly, the overall operating efficiency of property insurance companies is generally low, and there is still room for improvement. The overall efficiency of domestic companies is relatively low, which may be related to the long-term business philosophy(Paying much attention to scale development) of insurance companies in china. From 2009 to 2014, the operating efficiency of foreign property insurance companies showed a downward trend, which may be related to the impact of the global financial crisis. On the whole, the operating efficiency of domestic property companies is higher than that of foreign property companies except 2009.

On the one hand, although foreign-funded property insurance companies have certain advantages in business philosophy, product design, risk management and service level, they are more sensitive to changes in the international financial environment. On the other hand, domestic companies seize market resources and expand market share by virtue of their local development advantages and policy protection. Foreign companies have entered the Chinese market for a relatively short time, with more policy constraints and fewer branches, leading to their low operating efficiency.

\section{CONCLUSION}

The enlightenment of this paper is as follows: first, to speed up the transformation of domestic companies' management mode, from excessive expansion of extensive business mode to the mode of consigned development. This requires property insurance companies to pay more attention to the quality of business development and service level as well as enhance their technological innovation ability and core competitiveness while strengthening their risk control 
ability. Second, insurance companies need to improve their management efficiency and reduce their operating expense ratio. The company should actively increase the scale of assets by means of financing, pay attention to the professional investment management of insurance funds, and improve the return on investment. Domestic companies should strengthen the exchange of management experience and technical cooperation to achieve a win-win situation.

\section{References}

[1] Bertoni, F., Croce, A., The productivity of European life insurers: best-practice adoption vs. innovation. The Geneva Papers on Risk and Insurance - Issues and Practice, Vo1.36, No.2, 2011.

[2] Biener, C. Eling, M., Organization and efficiency in the international insurance industry: a cross-frontier analysis. European Journal of Operational Research, Vo1.221, No.2, 2012.

[3] Biener, C., Eling, M. and Wirfs, J. H., The determinants of efficiency and productivity in the Swiss insurance industry. European Journal of Operational Research, Vo1.248, No.2, 2015.

[4] Cummins, J.D. and Weiss, M.A., Measuring cost efficiency in the property-liability insurance industry. Journal of Banking and Finance, Vo1.17, No.2, 1993.

[5] Eling, M. and Luhnen M., Efficiency in the international insurance industry: a cross-country comparison. Journal of Banking and Finance, Vo1.34, No.7, 2010.

[6] Luhnen, M., Determinants of efficiency and productivity in German property liability insurance: evidence for 1995-2006. The Geneva Papers on Risk and Insurance - Issues and Practice, Vo1.34, No.3, 2009.

[7] Tone, K. A., Slacks-Based Measure of super-efficiency in Data Envelopment Analysis. European Journal of operational Research, Vo1.143, No.1, 2002.

[8] Weiss, M.A., International P/L insurance output, input, and productivity comparisons. Geneva Papers on Risk and Insurance Theory, Vo1.16, No.2, 1991. 